\title{
Detection of a Mycobacterium leprae cell wall antigen in the urine of untreated and treated patients
}

\author{
V K SHARMA, ${ }^{*} \mathrm{~S}$ KAUR, ${ }^{*} \mathrm{C}$ VAISHNAVI, $\dagger$ \\ $\mathrm{N}$ AGNIHOTRI, $\dagger$ I KAUR* \& N K GANGULY $\dagger$ \\ Departments of Dermatology* and Experimental Medicine $\dagger$, Post- \\ graduate Institute of Medical Education and Research, Chandigarh \\ 160012, India
}

Accepted for publication 30 July 1991

\begin{abstract}
Summary A total of 90 leprosy patients, 12 household contacts and 10 normal subjects were studied for the detection of $M y$ cobacterium leprae cell wall antigen in urine using monoclonal antibody $\left(\mathrm{ML}_{0} \mathrm{~A}_{2} \mathrm{IgG}\right)$. In untreated multibacillary leprosy (BL-LL) the $M$. leprae cell wall antigen could be demonstrated in the urine of $14(64 \%)$ patients by immunofluorescence (IF) and $22(100 \%)$ by ELISA. In untreated paucibacillary leprosy (TT-BT), it could be demonstrated in 3 $(11.5 \%)$ and in $13(50 \%)$ patients by IF and ELISA methods respectively. All but 1 household contact (later confirmed to have BL leprosy) and all 10 normal subjects' urine was negative for $M$. leprae cell wall antigen by both methods. The same antigen was, however, demonstrated in urine of $50 \%$ paucibacillary patients who had received 6 months of treatment and in $68 \%$ multibacillary patients who had received 24 months of WHO recommended multidrug therapy. $M$. leprae cell wall antigen assays in urine will not be useful in the follow-up of leprosy patients on multidrug therapy.
\end{abstract}

\section{Introduction}

The diagnosis of leprosy is based on cardinal clinical features like anaesthesia or hypoaesthesia, hypopigmented and/or infiltrated erythematous patches, nerve thickening and the demonstration of Mycobacterium leprae. Attempts have been made to diagnose clinical and subclinical leprosy by the demonstration of antibodies against $M$. leprae. ${ }^{1.2}$ Recently, it has been found that the demonstration of $M$. leprae antigens in serum is a better indicator of infection and may help in follow-up during treatment. ${ }^{3-6}$ Evaluation of $M$. leprae antigens excreted in urine ${ }^{7-10}$ will be of use in the follow-up of leprosy patients on treatment, early diagnosis of relapse and in the epidemiological surveys for the evidence of subclinical infection. " The present study was undertaken to assess the role of $M$. leprae cell wall $(\mathrm{CW})$ antigen assays in urine in the follow-up of patients on chemotherapy. The monoclonal antibody employed $\mathrm{ML}_{30 \mathrm{~A}_{2}} \mathrm{IgG}$ detects $35-70 \mathrm{kD}$ cell 
wall antigen named MY3. This antigen is found in $M$. leprae but is also shared by $M$. welchii, ICRC bacillus, M. lepraemurium and other mycobacteria. ${ }^{12} M$. leprae $\mathrm{CW}$ antigen assays were carried out by immunofluorescence (IF) and double antibody sandwich ELISA methods in both untreated and treated paucibacillary and multibacillary patients.

\section{Materials and Methods}

PATIENTS

We selected 90 leprosy patients who attended the Leprosy Clinic at the Nehru Hospital attached to the Postgraduate Institute of Medical Education and Research, Chandigarh, India for the study. These included 68 males and 22 females with disease periods ranging from 3 months to 15 years (mean 2.4 years). Out of 42 paucibacillary (TT-BT) cases 16 had received treatment with WHO paucibacillary multidrug therapy (MDT) for 6 months and the remaining 26 cases were untreated. Out of 48 multibacillary (BL-LL) patients 22 were untreated and 26 had received 2 or more years of WHO MDT. ${ }^{13}$ We also studied 12 household contacts of the untreated patients and 10 healthy subjects. The patients were classified according to the Ridley-Jopling classification. ${ }^{14}$ Diagnosis of leprosy was based on clinical, bacteriological and histopathological examinations and the slit-skin smears were done from 1 to 3 patches in TT-BT patients and 3 patches and both earlobes in BLLL patients. Dharmendra lepromin $(0 \cdot 1 \mathrm{ml})$ was injected intradermally in the left forearm of selected patients and readings were taken initially after $48 \mathrm{hr}$ and again after 4 weeks to see the lepromin response.

The renal status was assessed by routine urinalysis for albumin, sugar and microscopic examination for leucocytes, erythrocytes and casts. Urine culture for pathogenic microorganisms were done. Urine deposits obtained after ultracentrifugation were cultured into Lowenstein-Jensen media slants to look for M.tuberculosis. An estimation of blood urea and serum creatinine was also carried out in all patients.

Physical examination was done to rule out coexisting tuberculosis and renal diseases and a blood pressure reading was taken in all patients. A chest skiagram was carried out to rule out concomitant tuberculosis.

\section{DETECTION OF $M$. LEPRAE CELL WALL ANTIGEN}

Midstream urine (15-20 ml) was collected in 2 sterile glass culture tubes. One of them was sent for urine culture and urine from the second tube was centrifuged at 17,000 $\mathrm{g}$ for 20 min. Smears were made in duplicate on slides from the urine deposits. One slide was used for Ziehl-Neelson staining and another used for an IF study as detailed below.

$M$. leprae $\mathrm{CW}$ antigen was detected by IF and by an enzyme-linked immunosorbent assay (ELISA) in the urine samples.

\section{Immunofluorescence study}

The smears were rinsed in carbon tetrachloride for $10 \mathrm{~min}$ at room temperature and digested with $0 \cdot 1 \%$ solution of trypsin in Tris- $\mathrm{HCl}$ buffer $(\mathrm{pH} 8 \cdot 0)$ at $37^{\circ} \mathrm{C}$ for $1 \mathrm{hr}$. The smears were fixed in ice-cold acetone for $30 \mathrm{~min}$ and stored at $-20^{\circ} \mathrm{C}$ till further use. 
Monoclonal antibodies (ML30A $\mathrm{A}_{2} \mathrm{IgG}$ ) against $M$. leprae (kindly supplied by Dr J Ivanyi, Director of Tuberculosis Research Centre, London) were applied. The smears were treated with FITC conjugated anti-mouse immunoglobulins and the IF was recorded arbitrarily as $1+$ to $4+$ according to the degree of fluorescence observed. Nasal and slitskin smears from known untreated lepromatous patients were used as positive controls.

\section{Enzyme-linked immunosorbent assay (ELISA)}

The ELISA was performed by the double antibody sandwich method. Briefly, monoclonal antibodies diluted to 1:1000 were coated on polyvinyl microtitre ELISA plates. After thorough washing with phosphate-buffered saline (PBS) containing $1 \mathrm{~mm}$ $\mathrm{Ca}^{+}$and $0.02 \%$ Tween-20 (PBSCT) and blocking with bovine serum albumin, $100 \mu \mathrm{l}$ of urine deposit samples were added to the wells and incubated at room temperature for $3 \mathrm{hr}$. After 3 washes with PBSCT the wells were again treated with $100 \mu 1$ of $1: 1000$ monoclonal antibodies. Wash cycles were repeated 3 times followed by $100 \mu$ l of horse-radish peroxidase conjugated with rabbit immunoglobulins to mouse immunoglobulins diluted 1: 5000 in PBS. Incubation was carried out at $37^{\circ} \mathrm{C}$ for $30 \mathrm{~min}$, the wells washed 3 times and $100 \mu \mathrm{l}$ of freshly-prepared substrate $\left(\mathrm{H}_{2} \mathrm{O}_{2}\right.$ and orthotoluidine) were added. Incubation was done at room temperature for $30 \mathrm{~min}$, the reaction was stopped by adding $100 \mu \mathrm{l}$ of $3-\mathrm{N}$ sulphuric acid. Urine samples from healthy subjects and pretitrated $M$. leprae antigen served as negative and positive controls, respectively.

Absorbance was read at $490 \mathrm{~nm}$ in an ELISA reader (Dynatech Laboratories Inc, VA, USA). The mean of 3 optimal density (OD) readings was recorded for each sample. A sample was considered positive if its mean exceeded the mean +2 standard deviations of the negative control samples.

\section{Results}

All paucibacillary patients ( 26 untreated, 16 treated) were slit-skin smear negative. In the untreated multibacillary group (22 patients), the mean bacteriological index (BI) was $4 \cdot 1+$ and the morphological index was $2 \cdot 3 \%$. In the treated MB group (26 patients) all but 2 were slit-skin smear negative.

\section{LEPRAE CELL WALL ANTIGEN DETECTION IN URINE}

\section{Immunofluorescence method}

$M$. leprae $\mathrm{CW}$ antigen was detected in $3(11.5 \%)$ untreated paucibacillary patients, the degree of fluorescence was graded from $1+$ to $2+$. In multibacillary disease, the same antigen was detected in the urine of $14(64 \%)$ untreated and $10(39 \%)$ treated patients. The fluorescence was graded $2+$ and above in the vast majority of untreated multibacillary patients $(71 \cdot 4 \%)$ compared with treated patients $(40 \%)$ (Table 1$)$.

All 10 healthy individuals and 11 household contacts were negative.

\section{ELISA method}

Half of both untreated and treated PB patients were positive by this method. All 22 
Table 1. M. leprae CW antigen detected in urine of leprosy patients and controls by immunofluorescence

\begin{tabular}{|c|c|c|c|c|c|c|c|}
\hline \multirow[b]{2}{*}{ Subjects } & \multirow{2}{*}{$\begin{array}{c}\text { No. } \\
\text { studied }\end{array}$} & \multirow{2}{*}{$\begin{array}{c}\text { No. } \\
\text { negative }\end{array}$} & \multicolumn{4}{|c|}{ No. positive by IF } & \multirow{2}{*}{$\begin{array}{l}\text { Percent } \\
\text { positive }\end{array}$} \\
\hline & & & $1+$ & $2+$ & $3+$ & $4+$ & \\
\hline I Healthy individuals & 10 & 10 & - & - & - & - & 0 \\
\hline II Contacts & 12 & 11 & - & & - & $1^{*}$ & $1(8 \cdot 3)^{*}$ \\
\hline $\begin{array}{l}\text { III Paucibacillary lepros } \\
\text { (a) Untreated } \\
\text { (b) Treated }\end{array}$ & $\begin{array}{c}\text { y }(\mathrm{TT}, \mathrm{B} \\
26 \\
16\end{array}$ & 23 & $\begin{array}{c}1 \\
\text { Not }\end{array}$ & $\begin{array}{c}2 \\
\text { done }\end{array}$ & - & - & $3(11 \cdot 5)$ \\
\hline $\begin{array}{l}\text { IV Multibacillary lepros } \\
\text { (a) Untreated } \\
\text { (b) Treated }\end{array}$ & $\begin{array}{c}(\mathrm{BL}, \mathrm{L} \\
22 \\
26\end{array}$ & $\begin{array}{r}8 \\
16\end{array}$ & $\begin{array}{l}4 \\
6\end{array}$ & $\begin{array}{l}7 \\
3\end{array}$ & 2 & $\begin{array}{l}1 \\
1\end{array}$ & $\begin{array}{l}14(64 \cdot 0) \\
10(39 \cdot 0)\end{array}$ \\
\hline
\end{tabular}

* Positive household contact was later found to have BL leprosy.

Table 2. $M$. leprae $\mathrm{CW}$ antigen detected in urine in leprosy patients and controls by ELISA

\begin{tabular}{lcccc}
\hline & & \multicolumn{2}{c}{ M. leprae CW antigen } & \\
\cline { 3 - 4 } & $\begin{array}{c}\text { No. } \\
\text { studied }\end{array}$ & $\begin{array}{c}\text { No. } \\
\text { negative }\end{array}$ & $\begin{array}{c}\text { No. } \\
\text { positive }\end{array}$ & $\begin{array}{c}\text { Percent } \\
\text { positive }\end{array}$ \\
\hline I Healthy individuals & 10 & - & - & - \\
II Contacts & 12 & 11 & $1 *$ & $8 \cdot 3^{*}$ \\
III Paucibacillary leprosy (TT/BT) & & & \\
$\begin{array}{l}\text { (a) Untreated } \\
\text { (b) Treated }\end{array}$ & 26 & 13 & 13 & $50 \cdot 0$ \\
IV Multibacillary leprosy (BL, LL) & 16 & 8 & 8 & $50 \cdot 0$ \\
$\begin{array}{l}\text { (a) Untreated } \\
\text { (b) Treated }\end{array}$ & 22 & 0 & 22 & $100 \cdot 0$ \\
\hline
\end{tabular}

\footnotetext{
* One household contact positive by ELISA was later found to have BL
} leprosy. He was also positive by IF method.

patients (100\%) with untreated MB leprosy were positive and 17 (68\%) patients who had received 24 doses of WHO-recommended MDT were also positive (Table 2).

All 10 healthy individuals and 11 household contacts were negative by ELISA. The household contact positive by both IF and ELISA was later found to have BL leprosy. The ELISA titres in different subjects are depicted in Figure 1.

\section{Correlation between $\mathrm{M}$. leprae $C W$ antigen detection by IF and ELISA}

The 3 untreated PB, the 14 untreated MB leprosy, and the 10 treated MB patients who were positive by IF were also positive by the ELISA test, but those patients positive by the 


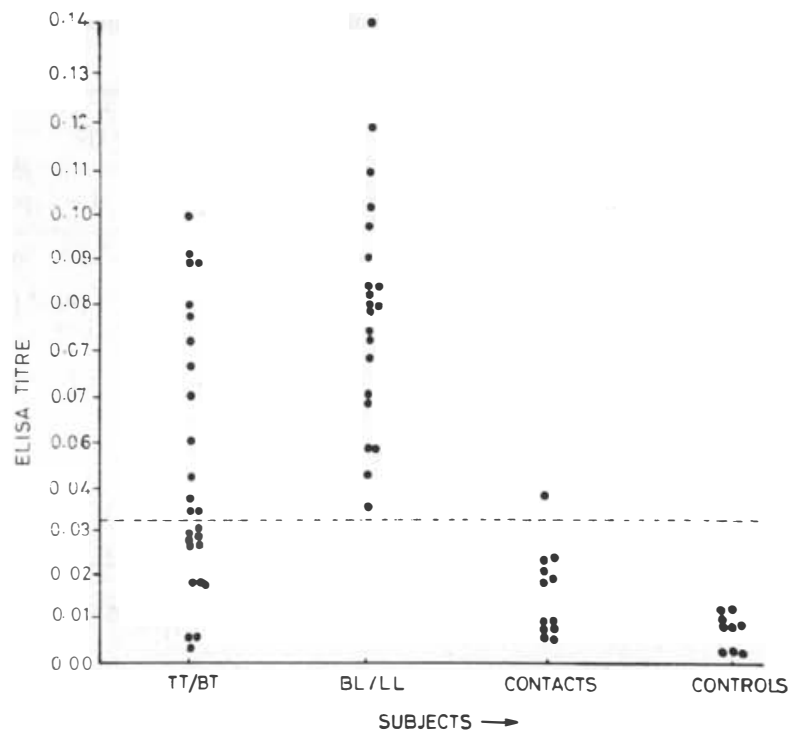

Figure 1. The scatterogram depicts ELISA titres in different subject groups. Each dot represents a sample. Note that specimens from all healthy controls and all but one household contact have insignificant ELISA titres whereas all BL and LL patients have titres above the cut-off line. Samples from TT and BT patients are equally distributed on both sides of the cut-off titre.

ELISA test were not positive by IF. It is apparent that the ELISA test is more sensitive in detecting $M$. leprae $\mathrm{CW}$ antigen in urine.

\section{Effect of treatment on $\mathrm{M}$. leprae $\mathrm{CW}$ antigen detection in urine}

There was apparently no effect of 6 months PB treatment on the above antigen excretion in the urine. The frequency of antigen excretion was, however, reduced in MB patients who received 24 doses of WHO MDT.

\section{Discussion}

The overt antigens of $M$. leprae, like those of all other mycobacteria, are carbohydrate based. The dominant carbohydrate epitopes of $M$. leprae are contained in 3 entities, the phenolic glycolipids (PGL), lipoarabinomannan and the arabinogalactan peptidoglycan complex. Though PGL- 1 is one of the first $M$. leprae specific antigen to be isolated, PGLII and -III have also been characterized. ${ }^{15}$

Ivanyi et al. ${ }^{12}$ detected 4 soluble antigens of $M$. leprae using 12 monoclonal antibodies employing radioimmunoassay, labelled antibody competition test and immunoblotting taken from polyacrylamide-electrophoresis gels. These antigens were arbitrarily labelled MY1, MY2, MY3 and MY4. A protein antigen MY1 found on M. leprae reacted with monoclonal ML06 and had no cross-reactivity with other mycobacteria. Similarly MY3 antigen of $M$. leprae reacted with monoclonal $\mathrm{ML}_{30 \mathrm{~A}_{2}} \mathrm{IgG}$, but this also occurs in 
M. welchii ICRC bacillus, M. lepraemurium, M. tuberculosis, M. bovis and M. scrofulaceum. MY3 antigen is associated with protein as it is highly sensitive to digestion by subtilisin and is also associated with 5 distinct fragments $(35-70 \mathrm{kD})$. Preliminary experiments indicated that MY3 antigen is associated with the cell wall as the repeated sonication of $M$. leprae cell pellet increased its yield in the supernatant fraction. The likely candidate for such a structure is the peptidoglycan cell wall. ${ }^{12}$

In the present experiment the coexistent tuberculosis was ruled out by clinical examination, chest skiagram and urine culture for $M$. tuberculosis. The other mycobacteria producing positive $M$. leprae $\mathrm{CW}$ antigen in urine is unlikely in the absence of clinical symptoms and moreover all but one of 22 controls ( 10 healthy controls and 12 household contacts) were negative for $M$. leprae $\mathrm{CW}$ antigen detection by both the IF and ELISA methods. The only household contact positive for $M$. leprae $\mathrm{CW}$ antigen was found to have BL leprosy.

Olcen et al., ${ }^{7}$ using radiolabelled armadillo derived $M$. leprae sonicate employing inhibition radioimmunoassay (RIA), found $M$. leprae antigenuria in 2 out of $23 \mathrm{~PB}$ patients and 11 out of $23 \mathrm{MB}$ patients. In the present study $M$. leprae $\mathrm{CW}$ antigen was demonstrated in similar proportions of both $\mathrm{PB}$ and $\mathrm{MB}$ leprosy patients by the IF method. The ELISA method for detecting $M$. leprae antigenuria was, however, more sensitive, being positive in $13(50 \%)$ PB and in all $22(100 \%)$ MB leprosy patients. Similar high antigen positivity was found for PGL-1 detection in both urine and serum. ${ }^{6,10}$ Olcen et al. $^{7}$ showed a significant correlation between the highest bacteriological index and antigen concentration in urine, contrary to our findings, even though the ELISA titres were much higher in $\mathrm{MB}$ patients compared to $\mathrm{PB}$ patients, contacts and controls (Figure 1).

Chemotherapy lead to rapid disappearance (4-8 weeks) of $M$. leprae antigen from both serum and urine correlating with a fall in the morphological index..$^{6,16,17}$ This is despite the fact that a large number of granulated or fragmented bacilli are known to persist in tissues even 4 years after treatment. ${ }^{18}$ However, in our series $M$. leprae antigen persisted in $17(68 \%)$ out of $26 \mathrm{MB}$ and $8(50 \%)$ out of $16 \mathrm{~PB}$ patients treated for 24 and 6 months, respectively, with WHO recommended MDT. This is due to the fact that the monoclonal antibody (ML30A 2 IgG) used by us detects a cell wall antigen $(35-70 \mathrm{kD}){ }^{15}$ which probably persists despite the chemotherapy. PGL-1 is synthesized and secreted by live $M$. leprae ${ }^{19}$ and hence its concentration falls soon after bactericidal treatment. ${ }^{16,17} \mathrm{We}$ therefore feel that $M$. leprae cell wall antigen assays in urine will not be of use during follow-up after treatment and for the early diagnosis of relapse.

\section{References}

1 Harboe M. Radio-immunoassay and other serologic tests and their application in epidemiological work. Lepr Rev, 1981; 52 (suppl 1): 275-8.

2 Douglas JT, Murry CJ, Lee JW, Worth RM. Comparison of ELISA antigens for early detection of preclinical leprosy. Abstracts of the XIIth International Leprosy Congress, New Delhi, 20-25 February 1984. Ind J Lepr 1984; 56 Suppl (No 1): abstract IX 1370 (A).

3 Young DB, Buchanan TM. A serological test for leprosy with a glycolipid specific for M. leprae. Science, 1983; 221: 1057-9.

4 Cho SN, Hunter SW, Gelber RH, Rea JH, Brennan PJ. Quantitation of phenolic glycolipid of Mycobacterium leprae and relevance to glycolipid antigenemia in leprosy. J Infect Dis, 1986; 153: 560-9.

5 Aguado-Sanchez G, Malik A, Tougne C, Lambert PH, Enjgers H. Simplification and standardization of 
serodiagnostic tests for leprosy based on phenolic glycolipid (PGL) antigen. Lepr Rev, 1989; 56: Suppl 2, 8393.

6 Chanteau S, Cartel JL, Celerier, Plichart R, Desforges S, Roux J. PGL-1 antigen and antibody detection in leprosy patients and evolution under chemotherapy. Int J Lepr, 1989; 57: 735-43.

7 Olcen P, Harboe M, Warndorff T, Belenu A. Antigen of Mycobacterium leprae and anti-M. leprae antibodies in urine of leprosy patients. Lepr Rev, 1983; 54: 203-16.

8 Kaldany RRJ, Nurligen A. Development of a dot-ELISA for detection of leprosy antigenuria under field conditions. Symposium on Immunology of Leprosy, Oslo, Norway, 1986. Lepr Rev, 1986; 57, Suppl 2, 95110.

9 Kaldany RR, Massho K, Ohman R, Reitz-Vick D, Britton S, Lefford MJ. Methods for the detection of a specific Mycobacterium leprae antigen in urine of leprosy patients. Scand J Immunol, 1987; 25: 37-43.

10 Singh NB, Choudhary A. Detection of antigenuria through dot-ELISA. Ind J Lepr, 1988; 60: 526-9.

11 Serological tests for leprosy. Lancet, 8 March, 1986: 533.

12 Ivanyi J, Sinha S, Aston R, Cussel D, Keon M, Sengupta U. Definition of species and cross reactive antigen determinants using monoclonal antibodies. Clin exp Immunol, 1983; 52: 528-36.

13 World Health Organization Study Group. Chemotherapy of leprosy for control programmes. WHO Tech Report Ser, 1982, No. 675.

14 Ridley DS, Jopling WH. A classification for research purposes. Lepr Rev, 1962; 33: 119-28.

15 Gaylord H, Brennan PJ. Leprosy and the leprosy bacillus: Recent developments in characterization of antigen and immunology of the disease. Ann Rev Microbiol, 1987; 41: 645-75.

16 Olcen P, Harboe M, Warndorff J, Diepen V. Antigens of $M$ ycobacterium leprae in urineduring treatment of patients with lepromatous leprosy. Lepr Rev, 1986; 57: 329-40.

17 Young DB, Harmsh JP, Knight J, Buchanan JM. Detection of phenolic glycolipid I in sera from patients with lepromatous leprosy. J Infect Dis, 1985; 152: 1078-81.

18 Rees RJW, Pearson JMH, Waters MFR. Experimental and clinical studies on rifampicin in treatment of leprosy. Brit MedJ, 1: 1970; 89-92.

19 Hunter SW, Fujiwara T, Brennan PJ. Structure and antigenicity of major specific glycolipid antigen of M. leprae. J Biol Chem, 1982; 253: 15072-8. 


\title{
Découverte d'un antigène Mycobacterium leprae de la paroi cellulaire dans les urines de sujets traités et de sujets non traités
}

\author{
V K Sharma, S Kaur, C Vaishnavi, N Agnihotri, I Kaur et \\ N K Ganguly
}

Résumé Une étude a été réalisée sur 90 lépreux, 12 sujets d'un même foyer en contact avec l'infection et 10 sujets sains afin de déceler dans les urines l'antigène Mycohacterium leprae de la paroi cellulaire, à l'aide de l'anticorps monoclonal ( $\left.\mathrm{ML}_{30 \mathrm{~A}_{2}} \mathrm{IgG}\right)$. Sur un groupe de sujets non traités atteints de lèpre multibacillaire (BL-LL), on a constaté la présence d'antigène $M$. leprae de la paroi cellulaire dans les urines de 14 patients $(64 \%)$ avec la technique d'immunofluorescence (IF) et $22(100 \%)$ avec la technique ELISA. Sur un groupe de sujets non traités atteints de lèpre paucibacillaire (TT-BT), la présence de l'antigène a été consta tée chez 3 patients $(11,5 \%)$ et 13 patients $(50 \%)$ avec la méthode d'immunofluorescence et la méthode ELISA, respectivement. Les urines de tous les sujets en contact, sauf un (chez qui la lèpre a été diagnostiquée par la suite) et des 10 sujets sains se sont révélées négatives d'antigène $M$. leprae de la paroi cellulaire avec les deux méthodes. La présence de ce même antigène a, cependant, été constatée dans les urines de 50\% des lépreux paucibasillaires ayant reçu 6 mois de traitement et $68 \%$ des lépreux multibacillaires ayant reçu 24 mois de médication mixte préconisée par l'OMS. La recherche d'antigène $M$. leprae de la paroi cellulaire dans les urines s'avère inutile pour le suivi médical des lépreux recevant un traitement mixte.

\section{La detección de antígeno de pared celular de Mycobacterium leprae en la orina de pacientes tratados y sin tratar}

\author{
V K Sharma, S Kaur, C Vaishnavi, N Agnihotri, I Kaur y \\ N K Ganguly
}

Resumen Se estudiaron 90 pacientes leprosos, 12 contactos de domicilio y 10 personas normales para la detección de antígeno de pared celular de Mycohacterium ieprae en la orina, usando anitcuerpo monoclonal (ML30A 2 IgG). En la lepra multibacilar (BL-LL) sin tratar se pudo demostrar la presencia del antígeno de la pared celular de $M$. leprae en la orina de $14(64 \%)$ de pacientes por inmunofluorescencia (IF) y en $22(100 \%)$ por ELISA. En la lepra paucibacilar (TT-BT) sin tratar, se pudo detectar en $(11,5 \%)$ y en $13(50 \%)$ de pacientes por los métodos IF y ELISA respectivamente. La orina de todos menos uno de los contactos de domicilio (que más tarde se confirmó tener lepra BL) y todas (10) las personas normales fue negativa al antígeno de pared celular de $M$. leprae por ambos métodos. Sin embargo, se demostró la presencia del mismo antígeno en la orina del $50 \%$ de pacientes paucibacilares que habían sido tratado por 6 meses y en $68 \%$ de pacientes multibacilares que habían sido tratados por 24 meses, por la terapia multidroga recomendada por la OMS. Las pruebas de orina por antígeno de pared celular de $M$. leprae no será útil en el control posterior de pacientes con lepra que reciben terapia multidroga. 